Yugoslav Federal Labour code in which the specified grounds for dismissal do not include the nebulous charge of "damaging social interests", and because it specifically excludes any right of appeal. Most seriously, they see it as a violation of the Universal Declaration of Human Rights and the Helsinki Final Act, both of which have been ratified by Yugoslavia. They conclude that such "arbitrary interference and discrimination constitutes not only an act of harassment but an act of imperilling the very conditions of existence of a scholar".

Vera Rich

\section{Scientists' pay \\ UK rumpus}

A decade of discontent among scientists in the British Civil Service will come to a head on 5 August, when the dispute about salaries for 1980 will go to arbitration. The most immediate issue to be settled is whether the Civil Service will accept the latest pay offer by the Civil Service Department (CSD). Underlying the dispute, in which the Institution of Professional Civil Servants has taken most of the weight, is whether existing methods for settling Civil Service pay should apply to scientists.

The chief humiliation in this year's pay offer is that some grades of the scientific Civil Service are to be offered no increase of salary. After a period in which the general level of salary increases in the United Kingdom has been running at something like 20 per cent, it is not surprising that passions have been roused.

Thus the salaries of those at the top of the Senior Principal Scientific Officer grade will, if the CSD proposal is unchanged by the arbitration award, remain unchanged between 1979 and 1980 .

Mr William McCall, general secretary of the IPCS, has said in a circular to his members that the offer of 1980 salaries is "disgraceful". The offer, if it is upheld by arbitration, may have repercussions outside the Civil Service, and among the staffs of research councils in particular.

The pay of scientists in the British Civil Service has been a contentious issue since the early 1970s, but the professionals within the service appear to be divided in how they would like to see the present arrangements changed. The ICPS bases its complaints chiefly on the use of what is called "pay research" to determine public servants' salaries.

This procedure entails the search for groups of scientists carrying out comparable work in the private sector of British industry. Quite independently, the use of pay research for determining civil servants' pay has recently been criticized in the United Kingdom on the grounds that the comparisons are flattering to the Civil Service and in any case take no account of the value of index-linked pensions to which retired public servants are entitled.

The IPCS objects to pay research because of the element of circularity which, it says, is likely to be introduced into the comparison because the Civil Service is the largest employer of scientists on research and development in the United Kingdom. But it also says that for some categories of senior people, suitable comparisons with private industry do not exist.

Other members of the scientific Civil Service are, on the other hand, anxious that there should be a more radical revision of the arrangements for regulating both pay and career prospects for scientists in the Civil Service. One body of opinion holds that the pay of scientists in the Civil Service compares well with that of scientists in,

\title{
Long-standing pay dispute continues
}

The dispute between the Civil Service Department of the British government and the Institution of Professional Civil Servants, the principal union representative of government scientists, has been rumbling on for two years. Since the early 1970s, the institution has reluctantly agreed that the pay of some categories of scientists should be determined on the recommendations of the Pay Research Unit Board, which is responsible for comparing civil servants' salaries with those of comparable groups outside.

The institution's misgivings about "pay research" for fixing the salaries of scientists stems from its belief that the Civil Service, which is the "largest single employer" of scientists working in research and development, is also a major influence on outside salaries. It also holds that pay research does not provide for the practice within the Civil Service of allowing for the promotion of individuals on the grounds of merit and says that career patterns outside are, in any case, quite different from those within the service.

The notion that civil servants should be fairly treated compared with people doing comparable civil work has been a cornerstone of Civil Service salary determinations since the Priestley Commission reported in 1956. More recently, however, the Fulton Commission on the organization of the Civil Service in 1968 advocated two further principles - the barriers between the scientific and the administrative branches of the Civil Service should be broken down and salaries in the two branches should be linked. From 1968 until recently, the salary scales of Principal Scientific Officers and of Principals (in the administrative branch) have thus been identical.

The first breach in this principle came last year, when Principal Professional and Technical Officers (including engineers) in the Civil Service were awarded a salary increase which, although three per cent above the general increase, gave them salaries which were $£ 729$ less than those of Administrative Principals.

This year, scientists within the Civil Service come off even worse. The offer from the Civil Service Department on 26 June, based on the work of the Pay Research Unit, would have increased the salaries of all but the more senior scientists in the Civil Service by between 14.0 per cent and 25.3 per cent. Senior Principal Scientific Officers, of whom there are more than 700 , were however offered no increase of salary, while it was proposed that four points should be added at the bottom of the salary scale to be occupied by future entrants.

Senior Scientific Officers and Principal Scientific Officers also fare badly, with increases at the top of the pay scales concerned of 9.1 per cent and 6.2 per cent respectively. More significantly, to many civil servants, the link with the salaries of Administrative
Principals has been broken - under the terms of the new offer from the Civil Service Department, the salaries of Principal Scientific Officers would in future be nearly $£ 2,000$ less than those of Administrative Principals.

The basis for the offer apparently rests, at least where the PSO grade is concerned, on the observation by the Pay Research Unit that in many industrial companies scientists are paid less than engineers. This has been held to justify the differential between the salaries of the Principal grades for scientists and engineers.

One of the issues in dispute between the Institution of Professional Civil Servants and the Civil Service Department is that of whether pay research can apply to the salaries of the small numbers of people in the grades of Senior Principal Scientific Officer and above. The CSD is insisting that comparisons with outside industry are possible at least for the SPSO grade.

There is also a dispute about the applicability of the agreed arbitration procedure.

\begin{tabular}{|c|c|c|c|}
\hline \multicolumn{4}{|c|}{ Maximum salaries offered for 1980} \\
\hline Grade & $\begin{array}{l}\text { No. in } \\
\text { service } \\
\text { (1979) }\end{array}$ & $\begin{array}{l}\text { Salary } \\
\text { offer }\end{array}$ & $\begin{array}{c}\text { Percentage } \\
\text { increase }\end{array}$ \\
\hline \multicolumn{4}{|c|}{ Senior Principal } \\
\hline $\mathrm{SO}^{*}$ & 728 & $£ 15,748$ & Nil \\
\hline Principal SO & 2,458 & $£ 12,050$ & 6.2 \\
\hline Senior SO & 3,830 & $£ 9,500$ & 9.1 \\
\hline Higher SO & 4,194 & $£ 7,900$ & 17.3 \\
\hline & 2,982 & $\{6,400$ & 16.7 \\
\hline Assistant SO & 3,120 & $£ 4,925$ & 22.2 \\
\hline
\end{tabular}

*SO $=$ Scientific Officer. 